\title{
THE FORMATION OF THE SPERMATOPHORE IN ARENICOLA AND A THEORY OF THE AITER- NATION OF GENERATIONS IN ANIMALS
}

\author{
ELLIOT ROWLAND DOWNING
}

FOUR PLATES AND SEVEN THXT FIGLRES

CONTENTS

Location of the gonads.................................. 1002

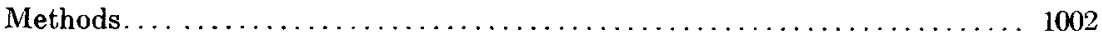

Limits of the gonads................................... 1004

General statement of spermatophore formation . . . . . . . . . . . . . 1006

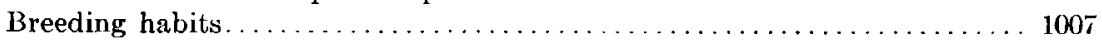

Degeneration and phagocytosis of the gonad ................... 1008

Extra blood vessels for aeration. . . . . . . . . . . . . . . . . . . . . . . . . . . 1009

Origin of the spermatogonia from peritoncal cells ................. 1011

Structure of the gonad ................................... 1012

The spermatophores, their formation........................ 1013

Their discharge into the body fluid. ....................... 1014

Their analogy to blastulae and gastrulae . . . . . . . . . . . . . . . 1015

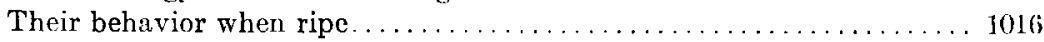

The giant spermatogonia .................................. 1017

Spermatogonial macromeres and micromeres................. 1018

The spermat ophore originates from one primary spermatogonium by a process

of cleavage and invagination................................ 1021

The spermatophore an individual-the gametozoon . . . . . . . . . . 1022

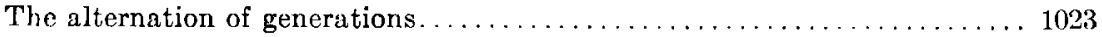

Botanic use of the term ................................ 1023

Usual zoological significance ............................... 1023

Alternation and chromatin reduction. . . . . . . . . . . . . . . . . . . . . 1023

Independent phenomena.............................. 1024

Chamberlain's theory of the alternation of generations in animals........ 1028

Objection to it ...................................... 1029

Limits of the gameto- and sporo-generations. . . . . . . . . . . . . . . . . . . 1029

Illustrated by graphic life histories . . . . . . . . . . . . . . . . 1030

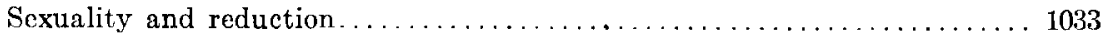

Adjacent phenomena................................ 1033

Not necessarily causally related $\ldots \ldots \ldots \ldots \ldots \ldots \ldots \ldots \ldots \ldots \ldots \ldots . \ldots \ldots \ldots$

The primitive animal type and the development of the alternation of generations as found in Arenicola................................ 1034 
The gametozoon $a \mathrm{x}$ form............................. 1037

The common plant and animal prototype ................... 1037

The primitive position of the reduction phenomenon .............. 1038

Its shift toward typical plant and animal positions. . . . . . . . . . 10:38

Reduction and tetrad formation........................... 1039

Beard's hypothesis of alternation of generations in animals........... 1039

Bibliography........................................ 1041

\section{LOCATION OF THE GONADS}

The gonads of the Arenicolidac are located on blood vessels which run diagonally across the surface of the nephridia.

The typical somites of these worms are composed of five annuli, one of which bears the setae. Three annuli are anterior and one posterior to this setigerous one. There are six pairs of nephridia in Arenicola cristata, situated in the fifth to the tenth somites inclusive, a pair for each somite. Each nephridium consists of a funnel, body and bladder. The funnel has a sagittate dorsal lip sel with ciliated plates and a lobed convex ventral lip; between the lips is the nephrostome. The body is club-shaped and connects, near its larger anterior end, with the funnel, at its posterior end with the bladder. The bladder is roughly spherical and opens to the extcrior by a narrow tube through the nephridiopore.

Each funnel is attached by the outside of the dorsal lip to the ventral surface of an oblique muscle, at some little distance from the attachment of the muscle to the body wall; so that the apex of the arrow-shaped funnel points downward and forward. 'The body of the nephridium passes up, back, and outward from its juncture with the fumel, to the bladker, which lies against the body wall close to the line of insertion of the oblique muscles to the sides.

\section{METHODS}

The ordinary method of pinning the animal out for dissection so pulls the nephridia that the shape, particularly of the delicate funnel, is distorted. The method followed has, therefore, been (1) to stupefy with 70 per cent alcohol, adding it rapidly, drop by drop, to just enough sea water, in a long dish, to eover the animal. Stupefaction, with complete relaxation of the powerful nuscles of the body wall cmsues, in A. cristata, in from ten to thirty 
minutes; in $\mathrm{A}$. claparedii, in from three to eight minutes. (2) With a hypodermic syringe, sufficient preserving fluid is injected to distend the body; the whole worm is then immersed in the preservative. After hardening, the nephridia, when dissected out, have the shape and relations described above.

Details of the methods of preservation will be reserved for a later paper in which the chromatin changes and other histological matters will receive attention. It will be sufficient now to state that testes preserved in strong Flemming, Bouin and vom Rath fixing fluids have given best results. The forming spermatophores have been studied in fresh body fluid, stained with methylen blue or neutral red; or in smear preparations killed by exposure to osmic acid fumes and fixed in Merkel or in vom Rath; or from sections prepared by squirting body fluid, freshly drawn, immediately into hot corrosive-acetic or Flemming, then hardening in alcohol in the usual way and sectioning in paraffin. Warm iron haematoxylin and Bordeaux red or saureviolett and fuchsin have been among the most successful stains.

Is the author has elsewhere published a description of the relations of the blood vessels to the nephridia in the Arenicolidae, the following brief description will suffice here. Fach nephridium of A. cristata is supplied with blood by a branch of the ventral blood vessel. This afferent vessel, on approaching the nephridium, branches to the setal sac and gill (if present), to the integumentary vessels, notably the dorsal-longitudinal, and to the nephridium. The branch to the nephridium cnters the anterior angle of the sagittate funnel and after traversing it, passes on to the upper surface of the body of the nephridium, which it crosses diagonally from the anterior inmer to the posterior outer side. Peripherad to the nephridium, it joins the nephridial longitudinal vessel. From the point of emergence from the fumnel on to the body of the nephridium to its juncture with the nephridial longitudinal vessel, the blood vessel is designated the gonadial vessel, since upon it the gonad is found. Gonadial tissuc is also found, to a slight extent, upon the nephridial longitudinal just anterior to its at tachment to the gonadial vessel (plate figs. 1-6). These figures show the location and relative size of the gonads in the several spccies. 
They are taken from typical nephridia and are drawn to the same scale. In each case the individual selected was an average sized worm and was taken at a time of the year, too, when the particular species was approaching the maximum of its breeding activity, so the gonad should have its maximum size. The extent of the gonad evidently varies greatly. It is confined to a relatively small area on the gonadial vessel in A. grubii and claparedii. It is much more extensive in A. cristata and about equally so in A. marina. The gonad achieves its greatest size in A. ecaudata. The relatively immense testes of this species are due to the fact that the sperm are retained within them until nearly mature while in the other species the spermatogonia are early discharged into the body fluid, there to undergo the major part of their development. The large bladders of the nephridia of A. grubii seem similarly due to the fact that they are used as storage rooms for the sexual products after their formation, while in A. cristata, marina and claparedii these are held in the general body cavity.

LIMITS OF THE GONADS

The gonad usually surrounds the blood vessel, It appears as a light yellow incrustation, varying in thickness with the scason. $A s$ it decreases in size it occupies a more and more restricted area on the posterior portion of the gonadial vessel. Not infrequently the other blood vessels adjacent to the nephridia, the dorsal longitudinal, the nephridial longitudinal and the nephridial branch of the afferent, are covered with a similarly appearing incrustation, but on microscopic examination, the material is found to bo chlorogonous, never gonadial. Furthermore, the gonad is confined to the blood vessels of the second to the fifth nephridia, inclusive, in A. cristata. Over a hundred males have been carefully examined: in $6.2 \mathrm{per}$ cent, one or both of the first nephridia had the gonadial vessel slightly to plainly coated with the yellowish incrustation: 11.3 per cent of them had the gonadial vessel of the sixth nephridium coated. Such nephridia have in all cases been removed and sectioned and with one possible exception, the sections show the incrustation to be chlorogonous. In a single instance the gonadial vessel of a sixth nephridium had upon it a fow cells looking 
like degenerating spermatogonia. As these worms were selected at intervals throughout the year so they would be representative, we may safely conclude that the vessels of nephridia one and six never bear active gonads, while there is slight evidence that the gonadial vessel of the sixth nephridium bears a degenerating gonad.

The limits of the gonads have not been as carefully studied in the other species of the Arenicolidae is in A. cristata. Yet I have exmained, macroscopically, several dozen specimens of each of the other species, claparedii, ecaudata, grubii and marina and have examined microscopically the blood vessels when any doubt could exist, with results confirmatory of the statements of previous authors, notably Gamble and Ashworth, as follows: A. ecaudata has thirteen pairs of nephridia in setigerous segments 5-17, A. marina six, in segments 4-9, $A$. grubii and A. claparedii each five pairs in segments 5-9.

Presumably the Arenicolidae have evolved from a more generalized polychacte in which nephridia and gonads were segmentally repeated organs. Both organs have gradually been confined to a smaller and smaller region. This gradual reduction seems to be well illustrated within the group as indicated by the number and position of the nephridia given above. Moreover, accordingto Gamble and Ashworth, the first pair of nephridia of A. marina are frequently absent and the last pair occasionally. Lillie remarks of the nephridia of $A$. cristata that "The two earliest formed pronephridia, those of somites iv and $\mathrm{v}$, degenerate at a comparatively early period in the development. 'The remaining six pairs (in somites VI-XI, inclusive) are directly transformed into the definitive adult nephridia." Fauvel ('99) states that the number of nephridia in $A$. ecaudata is only occasionally thirteen; that twelve is the usual number, the last pair of nephridia being absent from his specimens. In the two hundred and more specimens of 1 . cristata examined I have found only three cases of variation in the number of nephridia. In two of these the first pair of nephridia was wanting; in the third only the fumnel was present in the sixth right. I have yet to find variation in the other species. 
The gonads are more restricted than the nephridia. Is noted above, the first gonadial vessel in 1 . cristata never bears gonads, the sixth rarely and then degenerating cells only. In the other species the first nephridium never has a gonad. Here then is a case in which the genital cells show an evolutionary character, the tendency to restriction, more emphalically than the somatic cells.

\section{GENERAL STATEMENT}

A section through the testis of any of the Arenicolidae shows, ordinarily, a mass of cells of two or three sizes (fig. 7-9): These are the spermatogonia of successive generations. The larger ones lie adjacent to the blood vessel. At the periphery of the gonad spherical bunches of spermatogonia or occasionally single ones are seen to be loosening from the general mass preparatory to discharge into the body fluid (except in $\Lambda$. claparedii). In this fluid the further divisions of the cells result in the formation of hollow spheres of spermatogonia (fig. 10), the last generation of which grow to spermatocytes. These, by the customary two divisions, become the spermatids (fig. 11) the cells still adherent in the spherical masses, which are meanwhile however altering their shape and becoming saucer-shaped, in $\Lambda$. cristata (fig. 12) slightly biconvex in the other species, except in $\lambda$. claparedii, in which the successive divisions occur in the testis and the sperm are discharged into the body fluid. These sperm masses are the spermatophores, (fig. 13). The body fluid of A. cristata is loaded with these spermatophores (or with the eggs) except for a short time just after the discharge of the scx products, and in the other species, except claparedii, for weeks before the eggs are deposited. There are present, of course, other elements, body cells, chloragogue cells, etc., but the dominant objects are the eggs and the spermatophores. Finally the tails of the sperm are stiff and are aggregated into conical masses (fig. 12).

Toward the close of the breeding scason, I have found, both in A. cristata and $A$. claparedii, exceptionally large spermatogonia discharged singly from the gonad, in addition to the customary masses described above. These develop in a somewhat different and highly instructive manner, as will be described later. 


\section{BREEDING HABITS}

The breeding season at Woods IIole lasts, for A. cristata, from about the first of May until the end of August, attaining its maximum during June. The cylindrical jelly strings containing the eggs are found in the shallow water over the littoral mud flats at low tide, one end attached at the burrow of the worm. The string lies on the bottom almost afloat. From field and laboratory observations I conclude that the male lies adjacent to the female during the discharge of the eggs and simultaneously discharges the sperm through the nephridiopores. The following facts support the statement: (1) I have repeatedly captured both male and female at an egg string when the latter was just beginning to appear. That one frequently fails to find both animals is, I presume, due to the fact that they burrow with extreme rapidity. If the tail of an animal be exposed with one stroke of the digger it often disappears before the next stroke can be taken and only very hurried work makes capture possible. When two worms are at the same burrow the chances of getting both are not great. It is to be remembered also that it is necessary to capture the worms in order to determine the sex as there are no external differences. To determine the sex withoutkilling the animals I have examined a small drop of the body fluid withdrawn from the body cavity by means of a hypodermic syringe. The presence of either eggs or sperm can usually be determined by the naked eye. (2) The discharge of eggs and sperm has been seen to occur through the nephridiopores in worms kept in pans in the laboratory. (3) I have been reasonably sure that male and female were coopperating in the formation of the egg string in animals kept in aquaria in the laboratory. At best, however, the details of the process are obscure, since the animals, even when close to the glass, are pretty well covered with sand.

The conspicuous egg strings make $A$. cristata the easiest species to locate when depositing the eggs. The other species probably lay the eggs in the sand and débris among which they live. The times of their sexual maturity are fairly well established. A crislata is found to mature at about the same time at Naples as at 
Woods Hole, i.e., June to August (LoBianco). A. marina is captured with mature eggs and sperm at Woods Hole in the early spring, April and May. It is found mature on the English coast in the spring (the laminarian variety) and summer (the littoral variety) according to Gamble and Ashworth. My specimens of sexually mature A. ecaudata were taken at Plymouth in April as also were specimens of $\mathrm{A}$. grubii. The latter and A. claparedii I found mature at Naples in May. Both of them have been found breeding much earlier there (LoBianco), A. claparedii beginning as early as November and continuing throughout the winter and spring. By using a haemocytometer I have estimated the number of spermatophores per cc. of body fluid in a mature male at about forty million. Each spermatophore will average in the neighborhood of a thousand sperm. A good sized male A. cristata will easily contain twenty-five or more cc. of body fluid, that is, a quadrillion sperm, ready to be discharged when fertilization is to be accomplished.

\section{DEGENERATION AND PHAGOCYTOSIS}

At the close of the breeding season the body cavity of the male contains very little sperm. In only 10 per cent of the September specimens of A. cristata taken at Woods Hole was sperm present in any quantity In 60 per cent so little was presen t that it was impossible to determine the sex except by sectioning the gonads. During August and September the gonad is at its minimum size. This I have determined in two ways: First, by macroscopic examination. The gonad is apparent on the blood vessel even to the naked eye. Examination of the animals throughout the year, with record of cases in which the gonad is plainly evident on nephridia two to five, shows that in August and September the gonads show least frequently. They become plainer during the fall, achieve the maximum size from December to March and then gradually become smaller again. Second, the same results have been reached by making serial sections of nephridia for each month and making camera lucida drawings of the largest cross section of the gonad as compared with the blood vessel on which it lies. The third and fourth nephridia are used preferably for the com- 
parisons as they show the maximum gonad development. In September the blood vessel shows only a thin line of gonadial material in a very limited area. This grows rapidly from month to month until the gonad is of large size and is giving off spermatophores into the body cavity. Sections from the December and January worms show the maximum relative cross section of the gonad. It gradually decreases as its substance is given off into the body fluid as forming spermatophores during spring and early summer. During June the body cavity has its maximum of sperm. By the last of July and in August fibrous degeneration is evidently going on in the gonad (fig. 8-9), and the disintegrating remnants of gonadial tissue are being ingested by abundant phagocytes (fig. 14).

Though specimens of the other species have not been collected in such quantity as $\mathrm{A}$. cristata throughout the year, yet enough of each has been seen to make quite certain that the description given will equally well apply to them, making allowance for the changed breeding period, always excepting $A$. ecaudata.

By October the degenerative changes have ceased in $A$. cristata and multiplication of the gonad cells has begun again. A month before the gonad attains its maximum size the peripheral cells of the gonad are beginning to break away in small masses and float in the body fluid. The later development of these spermatophores goes on in the body fluid. In October the margin of the gonad appears entire in section; in February and later the margin appears very ragged as the masses of gonad material are constantly discharging (compare figs. 7 and 8 and text figs. 1 and 2).

\section{EXTRA BLOOD VESSELS}

It will be seen then that the maximum size of the gonad does not coincide with the height of the breeding season. This is marked rather by the greatest abundance of the mature spermatophores in the body fluid. In September the body fluid contains few or no sperm. By October they are appearing and steadily increase so that by November or December the fluid is crowded with the masses of developing sperm. An interesting development of the circulatory system gocs on simultaneously with this 
accumulation of growing spermatophores. During December the diagonal muscles in the region of the first nephridium especially and to some extent in the second are apparently becoming 'hairy.' This appearance is due to the numerous long, fine bloodvessels attached at one end to a large vessel, the other floating freely in the body fluid. Similar vessels have been noted before
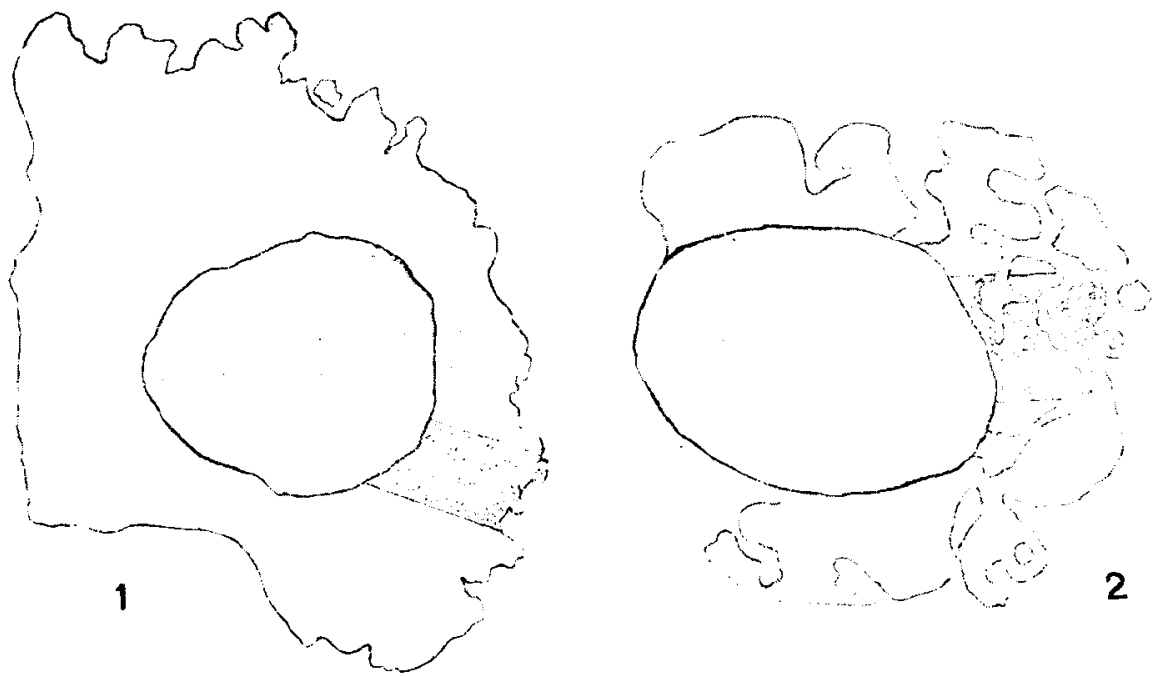

Text fig. 1. Outline of the testis of 1 . cristata in October. The gonarlial material lies around the blood vessel. 'The dotted arca corresponds to that shown in detail in fig. 7, pl. 2.

Text fig. 2. Outline of the testis of $A$. eristatia in liebruary. The doticd area corresponds to that shown in fig. 8 , pl. 3.

in .1. claparedii and .1. grubii by Gamble and . Lshworth (p. 518) with no suggestion as to their probable function. They seem evidently a device for the better aeration of the body fluid and the elimination of its wastes while it is heavily loaded with the devoloping spermatophores. They disappear in 1. cristata in early summer when the sperm are fully formed. 


\section{ORIGIN OF THE SPERMATOGONIA}

Lillie says of $\Lambda$. cristata:

The early germ cells in connection with cach nephridium become distinguishable soon after the appearance of the blood vessel of the latter and arise as a proliferation of the peritoneal eells of its walls. They appear first on the anterior and first formed portion of the vessel, i.e., in the region immediately adjoining the posterior angle of the funnel. The germ cells usually appear on their respective nephridia in the order of formation of these organs, i.e., in order from before back.

This peritoneum out of which the germ cells differentiate is derived from large teloblastic nuclei located at the posterior portion of the embryo in the growing zone, which nuclei Lillie thinks are the homologues of the definitc teloblast cells found in such forms as Clepsine and Lumbricus. They in turn are apparently direct descendants of $4 \mathrm{~d}$, one of the fourth quartette of blastomeres derived from the macromeres at the sixth cleavage, as described by Child.

I have endeavored, in Arenicola, to discover some constant characters in the germ cells, which, appearing also in certain of the peritoneal cells, would cnable me to trace the germ cells back through successive generations to the derivatives of $4 \mathrm{~d}$. But in this I have had no success and we must conclude that, as far as optical characters are concerned, the germ cells are indistinguishable by present methods from the other peritoneal cells. In other words, the differentiation of the germ cells is probably called forth by stimulation of adjacent cells due to progressive inherent changes.

Such a differentiation of the germ cells from the peritoneum is common in the annclida. "Die Bildungstätten der Geschlechtsproducte gehören bei den Ringwürmern genetisch den epithelialen Wandungen des Cöloms an und erscheinen in Folge diesen als directe Abkommlinge der Mesodermstreifon oder des secundüren Mesoderms." (E. Meyer, Studien über den Körperbau der Anneliden, III.) 
Gamble and Ashworth state (00, p. 31) in regard to A. mama that "In large Arenicola, at certain seasons, the vascular process has no gonad and it is possible, as (uenot ('91) suggests, that a formation of the amoeboid corpuscles of the coclom takes place at this point when the animal is not breeding." If this be true, evidently the gonad cells must form anew, as a proliferation of the peritoneal cells in adult life as well as in the embryological development and the distinetion of germ cells and soma would be hypothetical. If so, too, the annual appearance of the germ cells must be due to a cyclical change in the organism contemporaneous with or due to the seasonal change without. Of course this must be true of their rapid increase anyway.

I have examined many specimens of $A$. cristata taken in September in which the body cavity showed no sperm, sectioning nephridia on whose blood vessel naked eye examination showed no gonad, but have always found under the microscope some gonadial tissue. So that I feel reasonably certain that in this species at least, after once the primitive spermatogonia appear in the embryological development, they do not disappear.

\section{STRUCTURE OF TIIE GONAD}

These first few germ cells, then, formed trom the peritonal cells, multiply with rapidity until the entire gonadial vessel is covered with a thick incrustation of them. Division of the peripheral cells now becomes more rapid, so rapid in fact that the daughter cells do not grow to the size of the parent cells beiore division again ensues. There thus result zones of cells diminishing in size to the periphery of the gonad where they are being discharged into the body fluid. The largest cells, those adjacent to the blood vessel, are about $12 \mu$ in diameter in A. cristata $(11.67 \mu$ the average of over one hundred cells). The next smaller wize are $9.36 \mu$ in diameter, then $7.55 \mu$ and the outermost $6.02 \mu$. In 1 . claparedii and 1 . grubii the eells adjaent to the blood vesicel are smaller, only about $10 \mu$ in diameter.

Such an ideal arrangement of the cells is never found throughout the gonad. It some point s the largest sized cells will at times 
delay division until well out toward the periphery. The intermediate sizes may be scattered, with no apparent order, throughout the organ. Not infrequently, cells of the third or even second generation reach the edge and are broken from the mass to float in the body fluid separately or in larger or smaller groups. But frequently the typical arrangement described will hold for large regions of the gonad. The peripheral cells tend to cohere into roughly spherical masses of from ten to fifty or so cells all in the same stage of division and these break away into the body cavity. But smaller masses of cells may be detached, even single cells. In the body fluid division continues rapidly as will be described shortly.

\section{THE SPERMATOPHORE}

\section{Formation}

The largest spermatogonia, immediate descendants of the peritoneal cells, may be called the primary spermatogonia. During the year, except just before the height of the breeding season, these primary spermatogonia multiply, and after division, the daughter cells grow to the size of the parent cells except toward the periphery of the gonad. In the late fall and winter, in $A$. cristata collected at Woods Hole, the gonad is largely made of the primary spermatogonia; it presents quite a solid appearance. In the spring, however, division of these cells ensues so rapidly throughout the gonad, as it always does at the periphery, that the secondary spermatogonia do not have time to become as large as the primary ones before they divide in turn. Now the division of the cells derivative from a single primary spermatogonium, after it starts on its course of rapid subdivision, seems always to be roughly synchronous. The gonad taken during the fall and winter presents a somewhat mottled appearance along the margin when sectioned and stained, due to the prominence of these masses of cells in division among the relatively inactive primary spermatogonia. In the spring this mottled appearance pervades the whole gonad, for here and there a primary spermatogonium will start on its course of rapid subdivision, giving rise to two, then four, eight, etc., cells, which at first lie close together 
as a solid mass, but later have a cavity at the center, the segmen tation cavity. These forming spermatophores, for such they are, move to the periphery in order to break away into the coelomic fluid. So in spring and early summer the gonads have, when sectioned, a very ragged appearance. Deep bays and systems of lacunae run into the mass so that the spermatophores may be discharging not only at the periphery but are moving out from many spots in its interior (figs. 7 and 8).

There is frequently protoplasmic material at the center of this early spermatophore. It is derived from the disintegration of cells which, while the spermatophore is forming in the body of the gonad, come to assume a central position. Degeneration goes on as the cells move toward the margin of the gonad so that by the time the margin is reached little is left of the central cells. Occasionally strands of protoplasm run from some of the cells to a central point (fig. 15), suggesting a figure such as Calkins has shown for Lumbricus, as if the cell walls formed peripherally before they do centrally. This is an exceptional condition, however, and I am confident that no such interpretation is to be put upon it in Arenicola. Figure 16 is much more usual. In the more mature spermatophores one can, by carefully tapping the cover glass, cause the spermatogonia to break away from the central portion, leaving it as a colorless sphere containing occasionally a few granules. This does not ordinarily stain, has slight consistency and seems like a drop of slightly viscid fluid. Not infrequently even this disappears and the spermatogonia break away without leaving any residual mass. The central cells are then absorbed very early and the central remnant is possibly excretory in its nature, the products of anabolism that have diffused into the cavity.

\section{Discharge of the forming spermatophore}

The cells are customarily discharged, as has been stated, from the surface of the testis into the body cavity in roughly spherical masses. The constituents measure about $6 \mu$ in diameter in $A$. cristata. Three divisions at least follow and probably more, 
since the cells are growing at the same time they are dividing in the nutritive body fluid. Finally, the last generation of spermatogonia is formed, measuring about $2.9 \mu$. They transform into the spermatocytes of the first order, with a diameter of $3.2 \mu$. These divide to form the spermatids with a diameter of about $2 \mu$. In A. claparedii and $\mathrm{A}$. grubii the spermatids are somewhat larger, measuring some $2.4 \mu$ in diameter; in the other species the cells vary very little in size from the measurements given for $\mathrm{A}$. cristata.

\section{Analogy to blastulae}

There is thus formed a hollow sphere of cells, reminding one of the blastula of the segmenting egg (fig. 23). This likeness is even more emphatic when one follows the history of a single spermatogonium when freed from the surface of the testis. It will be recalled that as well as the spherical masses of several dozen cells, smaller masses, even individual cells, are discharged into the coelomic fluid, so that one finds in this fluid all stages in the formation of the spermatophore from the one-celled condition up to the completed structure. Naturally the resulting spermatophores vary very decidedly in size according as they have origin in a single discharged spermatogonium or in a coherent mass of such cells. Measurement of the mature spermmasses gives a variation, their diameters ranging from one to eight.

The single spermatogonium, floating freely in the coelomic fluid, divides into two, then four, eight, sixteen cells, etc., simulating in general appearance the cleavage of an egg. Further discussion of this matter will be taken up below when the division of certain giant spermatogonia is considered (figs. 17-25).

During the process of cell multiplication the forming spermatophore is constantly increasing in diameter. Since the cells form only a single layer, the smaller they become the thinner the wall of the sphere is and hence the larger it may be with a given amount of protoplasmic material. This protoplasmic material must also increase in amount during the spermatogonial divisions by appropriation of nutritive material from the coelomic fluid, for the spheres increase in diameter more than the mere thinning of their 
walls would account for. This is not true for the later stages, however, for with the formation of the spermatids a decrease in the size of the individual cells accompanies the transformation of the spermatids to the spermatozoa.

Contemporaneously with the change of the spermatids to spermatozoa, or even beginning when the cells are yet spermatocytes of the second order, a change in the shape of the mass of cells occurs. In A. cristata the spherical mass invaginates in a manner that forcibly suggests the invagination of some egg blastulae to form the gastrulae (fig. 24). The gastrula-like mass remains cup-shaped, the mouth wide open, the lips never approximating to suggest a closure of the blastopore. Usually before invagination is complete, the cup begins to flatten out, becoming saucershaped, which is the form of the mature spermatophore in this species (fig. 25).

This phenomenon is apparently merely analogous to the process of gastrulation in the egg. Presumably the physical relations: between the cell mass and the surrounding medium happen to be such that invagination ensues with regularity in this one species. Body fluid freshly drawn by means of a hypodermic syringe shows these gastrula-like forms, as do also preparations made by fixing the coelomic fluid in a variety of fluids. In other species no such thing happens, but the spherical mass of cells merely flattens out to form a biconvex spermatophore. There is however in the spermatogenesis of this group a phenomenon which is really homologous to the segmentation and gastrulation of the egg and which will be considered in the discussion of the giant spermatogonia.

\section{The ripe spermatophore}

As the spermatids transform into spermatozoa the cells elongate, their long axes at right angles to the surface of the saucershaped or biconvex mass (fig. 25). The nuclei stain with increasing intensity. The tails of the sperm appear as stiff rods, finely attenuate, held rigidly at right angles to the head and gathered 
together into one or several bundles (fig. 12). The head of the sperm is about $2 \mu$ in length, $1.22 \mu$ in transverse diameter, while the tail is ten to twelve times as long as the head.

When the coelomic fluid is drawn by means of a hypodermic syringe and placed in sea water, if the animal is not a perfectly 'ripe' male, the spermatophores remain intact, the rigid tails perhaps moving slightly but stiffly. If, however, the sperm masses be quite mature, those in this condition will show movements, the immature ones remaining quiescent. The tails move at first stiffy through varying arcs, the point of attachment to the head as the center. The bundles of tails disentangle and all the tails come to lie at right angles to the surface of the spermatophore. Now vigorous movements of the tails ensue, stiffly at first; then the tails become supple and undulatory movements begin. The spermatophore now disintegrates and the sperm swim away. This process is much more rapid if eggs be also adder to the soa water and more rapid still if some of the slime from the surface of the body of the female be put into the water.

\section{THE GIANT SPERMIATOGONTA}

The fact has before been mentioned that toward the height of the breeding season the margin of the gonad bears exceptionally large spermatogonia which are discharged singly into the body eavity. The primary spermatogonia in 1 . cristata are usually about 11 to $12 \mu$ in diameter. But these giant spermatogonia achieve a diameter of some $17 \mu$ before they are freed from the surface of the gonad to undergo their farther development in the eoelomic fluid. During July and Lugust they appcar in the gonads of 1 . cristata at Woods Hole. Similar cells were found in the gonads of $A$. claparedii collected at Naples the last of May and in A. grubii taken at Plymouth in August. It this time the margin of the gonad is very ragged, and fibrous degeneration with phagocytosis is going on in the parts adjacent to the blood resscls (fig. 8). 


\section{SPERMATOGONIAL MACROMERES}

The giant spermatogonium contains a very large nucleus and a prominent nucleolus (fig. 17). When shed into the body fluid the cell undergoes an interesting development. It divides unequally, producing one large and one small cell, (fig. 18). The small cell next divides, giving a three-cell stage. Unequal division of the large cell then occurs, producing a four-cell stage seen in polar view in fig. 19. It is so evident that these early stages in the division of the giant spermatogonia are at least roughly similar to the cleavage stages of the egg in Arenicola that we may modify the nomenclature of the latter to describe clearly the former. Just the order of cleavage of the four cells I have been unable to determine except that the three small cells divide before the large one, differing in this respect from the division of the egg blastomeres. When all have divided we have an eight-cell stage consisting of four large cells, the spermatogonial macromeres, and four small cells, the spermatogonial micromeres. The position of the cells (figs. 20,21), shows that the third division has evidently been a dexiotropic one as it is in the egg cleavage. Up to the sixteen-cell stage it is reasonably certain (and I think for at least one additional cleavage) that the cell lineage of these giant spermatogonia is homologous to that of the egg. Spermatogonial blastulae and gastrulae form much as in egg development. The figure of the sixteen-cell stage, (fig. 22) as indecd all these figures of the cleavage of the giant spermatogonia, are camera lucida cirawings done with exceptional care, under a one-sixth inch objective and a one-half inch ocular at the level of the table. It is needless to multiply sketehes as they would simply be duplicates of the admirable figures already given by ('hild for the cleavage stages of the egg.

Shortly after the sixteen-cell stage the macromeres disappear from the surface and migrate into the segmentation cavity. If one slightly crush the spermatophores in the body fluid under a cover glass, the great majority will show the blastophore exuding from the center of the spherical masses, yet a few will show four to six rather large cells which escape from the avity. This is 
especially true at the height of the breeding season. Spermatophores containing such cells are produced, I take it, from the spermatogonia that are liberated singly from the gonad, notably the giant spermatogonia. The large cells are the macromeres and possibly some of the first quartette-in other words, the homologues of the mesentomeres. The spermatophores consisting of a hundred or so cells never show such differences, all giving under pressure, the same so-called blastophore, apparently a drop of fluid, perhaps enclosed in a very delicate sheath, the fluid staining fairly dceply with methylen blue but scarcely at all with neutral red or other stains tried. It seems reasonably certain therefore that the invaginated mesentomeres disintegrate promptly to form the nutrition for the developing spermatophore.

It is manifestly difficult to detcrmine with exactness the order of cleavage and the relations of the cells. These enlarged spermatogonia occur only at the height of the breeding season and then make up a very small per cent of the developing spcrmatophores in the body fluid since these have been accumulated by the ordinary method for months. One must determine what occurs by the chance finding of successive stages, a laborious process, since the percentage of the desired material is so small. Presumably the cleavage of the giant spermatogonia might be watched if one could keep the body fluid under normal conditions. But it coagulates in the course of a few minutes after removal, the bodyfluid cells cohere in masses and all other cells, too, cease their activity. When stages are found in the development of these giant spermatogonia it is not easy to determine the exact relations of the cells; for the cell mass is small and transparent, even if stained; furthermore it is difficult to manipulate the cell mass without breaking it as it is only about one four-hundredth the size of the developing egg. Still I am confident of the above statements, as I have worked with the living material, stained whole mounts and sections. The results stated have been repeatedly confirmed during several summers at Woods Hole, working on 1 . cristata and have also been confirmed with the living and fixed material of $A$. claparedii and $A$. grubii. 
After my attention had been eaught by the peculiar egg-like clcavage of these giant, spermatogonia which float freely in the body fluid, I hunted carefully for the early developmental stages of the normal sized spermatogonia that are occasionally set free singly in the coelom. So far as I can find, their development is the same as that just described for the giant form.

One other interpretation might be suggested for these giant cells, namely, that they are tiny eggs which cleave in the body fluid to a certain point and then disintegrate. It is well known, of course, that such hermaphroditism of the gonad occurs when degenerative changes are going on in it. But such an explanation scems negatived in this case by the following considerations-

1. If they are developing eggs they would be undergoing cleavage long before they reach normal size, in fact when only about one four-hundredth of the size of the egg when it is normally ready to be fertilized and begin cleavage.

2. The normal sized spermatogonia undergo a similar cleavage when they are liberated singly in the body fluid.

3. At the height of the breeding scason, when these so-called giant spermatogonia are present, there are also found quite frequently giant spermatozoa whose volume bears about the same relation to the volume of the normal sized sperm as the volume of the giant spermatogonia bears to the volume of the usual primary spermatogonia.

It is to be noted that these exceptionally large spermatogonia appear toward the elose of the breeding season. It is at this time that the body fluid is supercharged with spermatophores, exidently taxing the respiratory and excretory organs to the limit of their capacity. For it is at this time that the blood ressel: develop in numbers like a thick growth of hair on the first and second nephridia and the adjacent muscles in $A$. cristata and in similar positions in the other species. At this time, too, the gonad is invaded by phagoeytes, while the portions adjacent to the blood vessel suffer fibrous degeneration. It seems quite likely then, since the respiratory organs are taxed to the utmost, that an oxygen starvation sets in in the gonadial tissue, indueing fibrous 
degeneration and phagocytosis. The growth of the giant spermatogonia may be due to the same general causer, the accumulation of wastes so changing the osmotic relations between cell content and the surrounding medium that an increase in size results, either from accumulation of materials customarily excreted or through increased absorption from the nutritive fluids that bathe the cell.

THH SPERMATOPHORE DEVELOPED FROM ONE SPERMATOGONICM

In the light of these facts regarding the development of the giant spermatogonia and those of normal size that float frecly in the body fluid, it is now worth while to review the formation of the ordinary spermatophores-those that are developing from the cells in the body of the gonad. A primary spermatogonium divides into two, four, eight cells, etc. Some of these cells move to the center of the mass and disintegrate to form the blastophore whose substance is absorbed as nutrition by the surrounding cells and is replaced by more or less excretory matter. Meanwhile the mass of eells is migrating toward the margin of the gonad. Arrived there, the nearly hollow cluster is given off into the body fluid where division of the component cells continues until the last generation of spermatogonia is formed. By a slight growth the cells are changed into the spermatocytes of the first order. The two customary divisions of the cells ensue and the spermatids are formed and then change to sperm. Meanwhile the spherical mass has changed its shape to the saucer-shaped or lenticular mass of the adult spermatophore.

It may seem an unwarrantable assumption that the ordinary spermatophores are the result of the segmentation of a single primary spcrmatocyte. The idea was suggested, rendered probable perhaps, by the development of the giant spermatogonia. It seems proven by the fact that all the cells in a given group manifest the same stage of division. It certainly presents a striking appearance, (figs. 8 and 9), to have a group of cells-a spherical bunch-all in the early prophase, for instance, when the adjacent cells manifest no sign of division. The possibility has 
been considered that, perchance, some influence emanates from the central cell of a fortuitously accumulated mass as this cell divides, which, passed on to the adjacent cells, causes them to divide also. One is at a loss however to see why the influence should not be passed on to the still more peripheral cells so that all the cells of the gonad would divide more or less in unison.

It is proper to speak of the division of these cells as synchronous only in a general way. It must not be taken to mean that each phase of division occurs in all simultaneously, merely that certain prophase and telophase conditions, that anyway last for a considerable time, are frequently found in all or nearly all cells of the group at once, so that the cells of the group in some stage of division, not necessarily exactly the same, will contrast with the surrounding tissue.

One finds these synchronous cells more or less disconnected at times, as if the stress of the neighboring growing cells had broken the integrity of the mass. Still the general harmony of division is maintained, as would be the case if the blastomeres of a four- or eight-cell stage in a developing egg were separated by mechanical means. When this does occur the separated spermatogonial blastomeres apparently proceed to form spermatophores of a fourth or an eighth the normal size, thus readily accounting for the previously noted variation in the size of the spermatophores.

\section{THE SPERMATOPHORE THE GAMETOZOON}

It seems evident, then, that the development of the primary spermatogonia in the gonad, the same spermatogonia, when shed singly into the body cavity, and the giant spermatogonia are all in accord and are sufficiently suggestive of the development of the individual derived from the egg to make the hypothesis quite plausible at least that we have in Arenicola an alternation of generations. The primary spermatogonia are asexual spores, each of which, cleaving in a manner quite analogous to the cleavage of an egg, produces an individual, the spermatophore, all the cells of which are transformed into gametes. 


\section{THE ALTERNATION OF GENERATIONS}

There follows the union of the sperm and the egg, the second individual in the alternation, what we ordinarily know as the adult worm. This individual it is that produces the spermatogonia or oogonia, or in other words, the asexual spores.

\section{Botanic use of the term}

The conception of the alternation of generations has developed in its clear-cut simplicity among the botanists. It is that in the life history of a form there are two generations, one of which produces sexually, the other by asexual spores. It is typified in the bryophytes and most pteridophytes. In the higher plants the sexual or gametophyte generation is gradually reduced so that it is only in relatively recent times that its existence as such has been recognized in the phaenogams.

\section{Usual zoological significance}

The term alternation of generations has been used by zoologists in a totally different sense. Two generations occur in many animals, the so-called sexual and asexual. The latter originates from a fertilized egg; the former arises by budding or a similar process from the asexual generation. There is thus an alternation of a generation that reproduces sexually with one that is never sexual, but the latter does not reproduce by asexual spores as is the case in plants. It is unfortunate that the same term is used for both processes. The asexual generation in the animal alternation is much more comparable to the sporophyte which is produced in propagation by cuttings or by runners. I am using the term alternation of generations strietly as it is understood by botanists.

\section{ALTERNATION OF GENERATIONS AND REDUCTION}

Now in all except the lowly plants, in all the archegoniates and even in many algae this alternation of generations is accompanied by the phenomenon of chromatin reduction, and reduction seems 
always to occur with definite relation to the alternation. The gametophyte, the plant that gives rise to the sexual elements, bears the reduced or haploid number of chromosomes. The sporophyte, the generation that produces the asexual spores, has the diploid or somatic number. Reduction occurs at the time the asexual spores are produced. So generally is this true, that for a time in many botanical papers, the presence of the diploid number of chromosomes was looked upon as a criterion that the cell possessing this number belonged to the sporophyte; or is a gametophyte cell if it has the haploid number, and the conclusion reached in a study of the archegoniates is forced, on a priori grounds, to cover the thallophytes as well. Thus Yamanouchi speaking of Williams' work on Dictyota says "The fertilized egg nucleus gives rise to an asexual plant with double the number of chromosomes and consequently a sporophyte generation." (Bot. Gaz., vol. 42: p. 431). And again, quoting from Davis, "Morphologically we can distinguish sporophyte plasm from gametophyte plasm by the double number of the chromosomes." (Am. Nat., vol. 39: p. 456).

In subjecting this life history [of Coleochaete] one of the green algae to what is regarded as a critical test of the two generations it has been discovered that this special spore-producing body is not a sporophyte. The test has to do with the number of chromosomes in the nucleus, a number which is definite for each plant species. The chromosomes are doubled in number by the fusion of the sperm and ege to form the oospore; and this means that in some other point in the life cycle the number must. be reduced again. $\Lambda$ ccordingly the sporophyte, which arises from the oospore, is characterized by the double or $2 x$ number of chromosomes in its nuclei; and the gametophyte, which gives rise to the gametes, is characterized by the reduecd or $x$ number of ehromosomes. Text book of Botany, Coulter, Barnes, Cowles; vol. 1, p. 32.

\section{Alternation and reduction independer:}

Recently, however, cytological studies on botanical material have thrown serious doubt on this conception. Reduction and the alternation of generations are, even in plants, independent phenomena. I shall briefly cite three lines of evidence in proof of this proposition. The few papers to which I refer will give references to abundant literature. 
1. It is proven by cytological studies on aposporous and apogamous material. By 'apospory' (Vines, Journal of Bot., '78, p. 355 ) is meant the direct production of a gametophyte from the tissue of a sporophyte without the intervention of a spore. 'Apogamy' (DeBarry, Bot. Zeit., '78, p. 449) means the growth of a sporophyte as a vegetative outgrowth from the gametophyte. This definition is tentative, as later writers, Strasburger, Farmer and Digby, etc., are not yet agreed on the limitations of apogamy and parthenogenesis.

Farmer and Digby succeeded, in four forms with which they experimented, in inducing apogamy, causing the omission of sporogenesis. They derived the prothallia directly from abortive sporangia or from pinnae. Such gametophytes have approximately the diploid instead of the usual haploid number of chromosomes. They conclude therefore "that there is no necessary relation between the periodic reduction in the number of chromosomes and the alternation of generations."

Again, Yamanouchi, in his study of apogamy in Nephrodium, obtained a sporophyte with the haploid instead of the customary diploid number of chromosomes.

2. The independence of the alternation of generations and reduction is further demonstrated by the fact that reduction may occur before, after, or during the sexual act, that is, in either the sporophyte or the gametophyte generation. I realize that in such a statement of the argument I am begging the question. I am merely stating the facts as they appear from my standpoint.

Whether the sporophyte and gametophyte of the archegoniates are phylogenetically continuous with the spore-bearing and gamete-bearing generations of the algae or whether the sporophyte of the archegoniates is a new structure, developed out of the fertilized egg and unrelated to the spore-bearing generation of the ancestral alga is a moot point. Botanists are far from agreed as to the course of the evolution of the higher plants from their algal ancestors. The Chlorophyceae has been designated the probable ancestral group and both Chara and Coleochaete are pointed out by different investigator's as probable connecting links. With equal conviction other botanists, notably Schenk recently, 
discard these forms as pathways of ascent and adopt the Phaeophyceae as the most likely progenitors of the higher plants. Still others believe some common ancestors of these groups, a form now extinct, to have been the starting point of the archegoniates. Disagreeing over the probable course of evolution, they are equally at variance on the moot point mentioned above.

Insuperable difficulties seem, so far, to stand in the way of tracing the evolution of the sporophyte of higher plants from the so-called rudimentary sporophyte which develops from the fertilized egg of such forms as Oedogonium, Ulothrix and Coleochaete. In these forms the egg, after fertilization, breaks up into a number of separate cells, each of which gives rise to a new plant, thus functioning in a way suggestively like the asexual spores of the archegoniates. In Coleochaete, the only one of the lot that approaches the Hepaticae in structure sufficiently to be considered a probable ancestor, this structure can not be considered a sporophyte unless it be one with the $x$ number of chromosomes instead of the $2 x$, in which case it is difficult to see how it gives rise to the sporophyte of the higher forms, which is usually characterized by the $2 x$ number.

In quite as many algae, Sphaerella, Volvox, Vaucheria, Chara, Fucus, Dictyota, etc., the fertilized egg, possibly after a rest period develops directly into the spore-bearing generation. It may be invidious for a zoologist to suggest that the sporophyte of the higher plants has arisen from this class of algae, by the inclusion of the spore-bearing generation of an alga within the gametebearing generation, somewhat as in Volvox one individual is included within the other. And I will not even venture the suggestion but will merely call attention to the fact that botanists are still not in sufficient agreement as to the course of the origin of the sporophyte in the archegoniates to prejudice, by their plant evidence, a zoologist against a theory along this line for animals. It is such a point of view that I take, namely, that in animals, and possibly also in plants, the spore-bearing and gamete-bearing generations of the protozoa (and algae) are phylogenetically continuous with the sporozoon (or sporophyte) and the gametozoon (or gametophyte) of the higher forms. 
With such a position in mind, I have a right to take evidence on the independence of reduction phenomena and the alternation of generations from the algae and protozoa. Moreover I have the precedent set by eminent botanists who use Coleochaete, Fucus, Polysiphonia, etc., as examples of the alternation of generations in the algae and base their theories of the rise of the phenomenon on such algal evidence.

Karsten has shown that the mitoses in the zygote of Spirogyra are reduction mitoses. The same is true of the Desmidaceae. These mitoses occur, of course, after the fusion of the egg and sperm. In Fucus, reduction occurs in the division of the antheridial and oogonial initials; in the case of the egg, the reduction is three mitoses prior to fertilization. (Yamanouchi.) In the Dictyotaceae, the cells of the tetrasporangium are the seat of the reduction division (Williams). Yamanouchi has shown that in Polysiphonia it is in the division of the tetraspore mother-cells that reduction occurs, while Wolfe claims that in Nemalion reduction occurs at the time of carpospore formation. Davis is so impressed with the fact that among the algae reduction occurs at so many different phases of the life history that he concludes that the phenomenon has a multiple origin. He says:

All of these cells in being the seat of reduction mitoses are analoguus to the spore mother cells of archegoniates, but that would not warrant their boing considered homologous with the latter structures. There is, on the contrarv, good reason to believe that, in plants, reduction phenomena became established as features in the life histories of a number of groups quite independently of one another, as the evidence indicates was also tiue of the processes of sexual evolution and the differentiation of the sporophyte generations. (Am. Nat. 43: 109).

Similarly among the protozoa we find the reduction phenomena occurring at various times. In Adalia (Siedlecki) and Monas (Prowazek) reduction occurs by the formation of chromidia in the gametes before they unite. Neresheimer and Metcalf find that in Opalina reduction occurs before the gametes form. Schaudinn has shown that in Actinophrys the cytoplasm of the conjugating individuals unites and then a reduction of the nuclei occurs. 
Dangeard thinks that reduction occurs during germination in Chlamydomonas. Prowazek's work on Polytoma indicates that the same is true in this form. Illustrations might be multiplied. Hertwig, years ago, after careful study of many protozoa, concluded that either before, after or during the sexual union there is a reduction division.

3. Among the protozoa and algae already cited, it is evident that reduction occurs when there is no alternation of generations.

\section{CHAMBERLAIN'S THEORY}

I have at some length presented what seems to me good evidence of the proposition that the alternation of generations and reduction are independent phenomena. I have been anxious to make the matter emphatic, otherwise, in any comparison of the alternation of generations in the higher plants and animals, unwarranted conclusions are reached. Thus Chamberlain, in proposing a theory of the alternation of generations in animals says,

The egg with the three polar bodies constitutes a generation comparable with the female gametophyte in plants; similarly, the primary spermatocyte with the four spermatozoa constitute a generation comparable with the male gametophyte in plants. All other cells of the animal constitute a generation comparable with the sporophyte generation in plants, the fertilized egg being the first cell of this series.

In support of this theorv I shall present two lines of evidence: (1) the gradual reduction of the gametophyte in plants, with the constantly diminishing interval between the reduction of the chromosomes and the process of fertilization; and (2) the phenomena of chromatin reduction in both animals and plants.

Briefly, his argument is this: that since, in the higher plants the gametophyte is gradually reduced, producing a condition apparently identical with that in animals, the egg and its three polar bodies and the spermatids of animals are to be regarded as tetraspores and the gametophyte generation is undeveloped except as represented by these cells: that these cells are further proven tetraspores because, in their formation, reduction occurs in a manner very like the reduction in the formation of the tetraspores of the higher plants. 


\section{Objections to Chamberlain's theory}

The facts adduced in the formation of the spermatophore of Arenicola and the evidence cited above to show the independence of reduction and the alternation of generations lead me to doubt both the validity of his argument and the accuracy of his conclusion. We are concerned at present only with his argument.

The fertilized egg of a lily is the first cell of the sporophyte, whether it ever divides at all. Consequently, we regard the zygospore of Ulothrix or Spirogyra and the fertilized egg of Vaucheria or Oedogonium as sporophytic structures, even if the first division of the zygote should be meiotic, as seems probable. From such a simple beginning, we believe that the more complex sporophytes with more conspicuous alternation have been developed. (Am. Nat. 44: 603).

\section{LIMITS OF GAMETOPHYTE AND SPOROPHYTE}

The gametophyte and sporophyte generations must be marked off, then, it seems to me, by some limits independent of the phenomena of reduction. A much safer means of definition is to return to simple conceptions and designate that generation the gametophyte which had its origin in the asexual spore and which terminates with the formation of the egg. The sporophyte generation begins with the fertilized egg and terminates with the formation of the asexual spore. Presumably all would agree that this means of distinction is the best; the only reason for relying on any other criterion is the difficulty of applying this one.

Yet to insist that the conclusion reached in the study of the archegoniates that the $2 x$ number of chromosomes marks the sporophyte, a law not without exceptions, even in the archegoniates themselves, shall apply in the algac, protozoa and higher animals too, seems to me unwarranted, for it drives one to the conclusion that as great a reduction has occurred in the gametophyte among protozoa and algae, Fucus, for instance, as has occurred in the whole evolution of the archegoniates from lowly Hepaticae to the most specialized angiosperms; and because there is another possibility, namely, that the reduction phenomenon, in thecourse of evolution, shifts its position with reference to the boundaries of 
the gametophyte and sporophyte generations in the life history of plants and animals--a possibility that, to me, scems more plausible.

In algae and protozoa alike we have the usual asexual reproduction followed by the sexual method, when some change in the physical or chemical condition, either of environment or organism, is an active cause. 'This is apparent from Calkins' studies on the conjugation of Paramoecium, Kleb's work on the formation of the gametes in Hydrodictyon and similar papers that followed these pioneer investigations. In these forms, as in most algac and protozoa, there is an intercalation of sexual among asexual generations, rather than an alternation. But let those conditions which produce sexuality recur with rhythmic regularity and an alternation is developed such as we have in Dictyota. We may presume that, phylogenetically, the higher forms exhibiting the alternation of generations have arisen from those lower ones that possess an intercalation of the sexual among the asexual generations. Further discussion of the point may be deferred and the alternation in Arenicola presented more fully.

\section{Graphic life histories}

In Arenicola the individual male is a sporozoon giving rise to certain cells, the spermatogonia, which are really the microspores. These cleave in a manner homologous with the cleavage of the egg and give rise to the gametozoon or the spermatophore whose development is a curtailed recapitulation of the primitive gametozooic generation. At the end of this generation reduction occurs during gametogenesis. The union of the gametes initiates the sporozoic generation again. This life history may be graphically represented by the conventional diagram I, (text fig. 3).

In the higher dioecious plants we should have a very similar graphic life history, see diagram II, except for the fact that reduction occurs at a different point. Comparing merely these two life histories, it seems difficult to homologize the gencrations, simply because so important a phenomenon occurs at such widely separate points. Not only does reduction occur at different phases of the life history of the higher plants and animals, but 

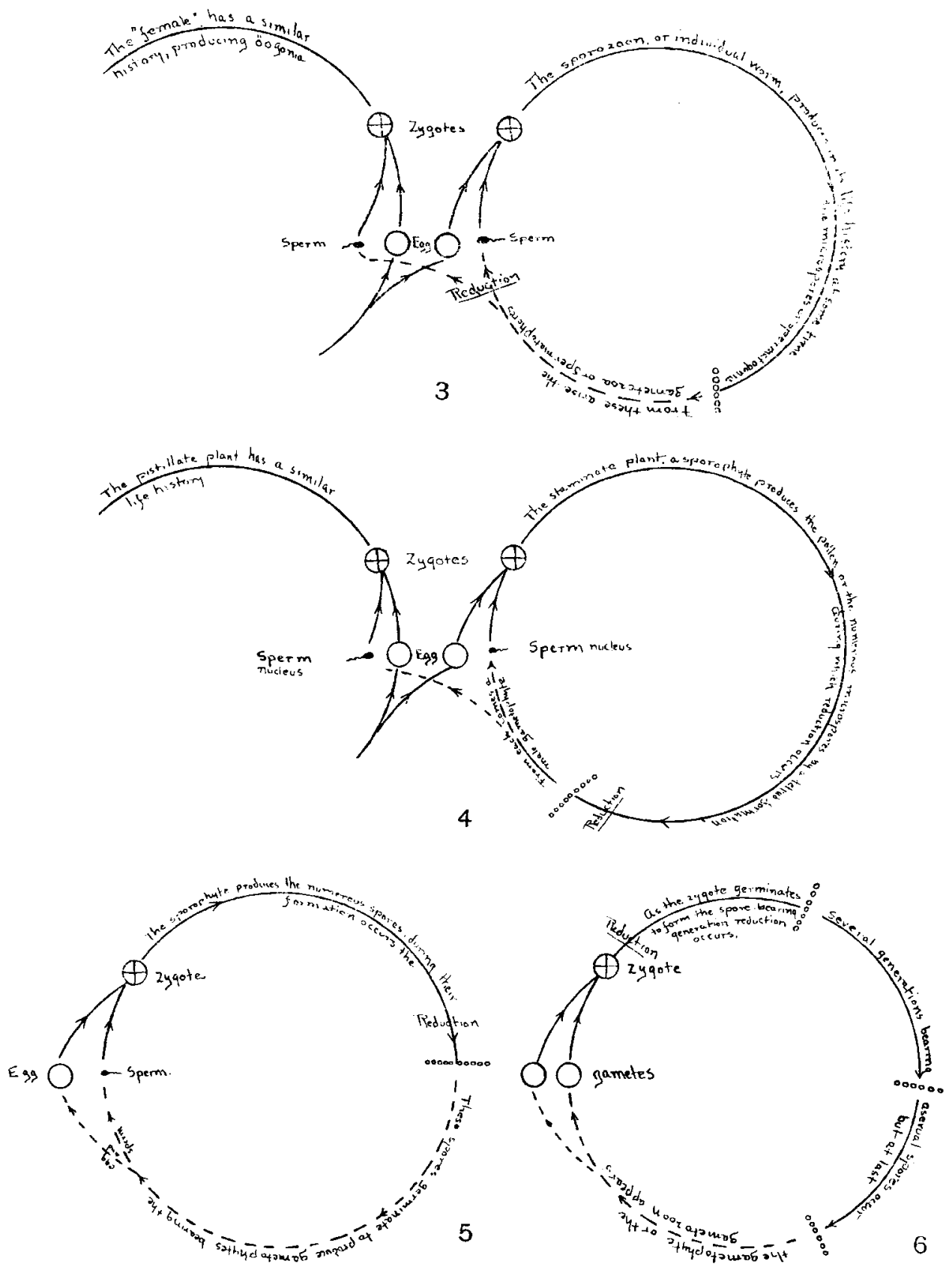

Fig. 3. Diagram I. Schematic representation of the spermatogenesis and alternation of generations in Arcnicola.

Fig. 4. Diagram II. Scheme representing the life history of a phaenogam.

Fig. 5. Diagram III. Scheme of the life history of the moss or other bryophyte.

Fig. 6. Diagram IV. Scheme of the life history of such an alg:t as spirogyra or such a protozoon as Chamydomonas. 
this is true, too, in the algae, as already pointed out. Let us review the facts down into that group with diagrams.

The mosses, (diagram III), show a sporophyte and gametophyte generation of about equal importance. The egg and sperm are usually borne on the same gametophyte.

The sporophyte becomes less and less prominent in the archegoniates as we approach the algae. Among the green algae the intercalation of a sexual generation seems the rule rather than the alternation of generations. The life history of Spirogyra, of the Diatomaceae, and of such protozoa as Chlamydomonas and Poly-

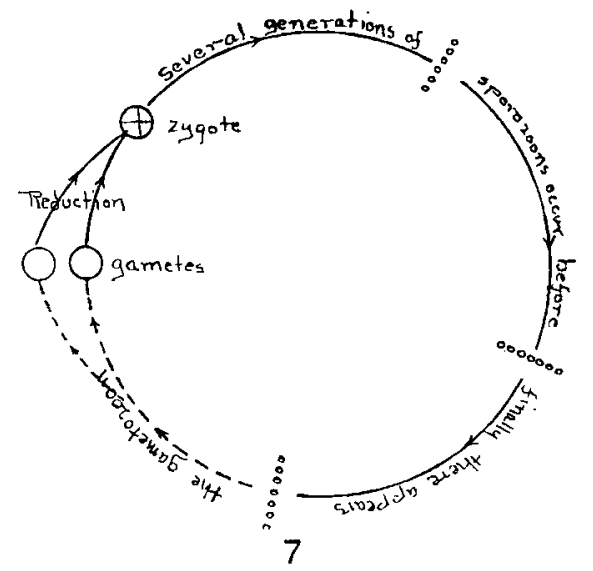

Fig. 7. Diagram V. Scheme of the life history of Adelia, Monts, ete.

toma would be graphically shown in diagram IV. In such forms as Adelea, Monas and Actinophrys among the protozoa, in no algae so far as I know, reduction occurs during the fusion of the gametes; the life history is given in diagram $\mathrm{V}$ (text fig. 7).

Now which of these life histories most nearly approximates primitive conditions? The question involves a discussion of the relation in phylogeny of the alternation of generations, sexuality and reduction. The evidence already given shows that the latter two phenomena antedate the alternation of generations, for both are found among simple animals and plants that have not achieved the alternation. 


\section{SEXUALITY AND REDUCTION}

Many biologists are inclined to regard sexuality and reduction as causally related. Thus Davis says "Chromosome reduction as a physiological process seems to be a corollary of sexual nuclear functions." (Bot. Gaz., vol. 43: p. 109.) If either were the effect of the other, we should expect reduction to bear a fixed relation to the sexual act. As it is we have seen that it may occur before, during or after such act. It would be better to say, then, that reduction is an adjunct of sexuality and both are probably corollaries of some fundamental cause yet to be determincd.

It has been suggested by Bütschli and later writers that the union of the gametes is a process of rejuvenescence. In other words, the sexual act is induced by exhaustion of the organism. We know that chromidia are due to degeneration produced by exhaustion and otherwise (Dobell, '07). Further, a very simple type of reduction has been found in some protozoa (Monas, Adelea, etc.) to consist of the extrusion of chromidia. The very incomplete state of our knowledge regarding reduction, chromidia and sex, particularly among the lower plants and animals, makes the proposal of even a working hypothesis premature. I call attention to the exhaustion of the organism through repeated asexual divisions as a possible cause of both sexual union and reduction, merely to illustrate the possibility that both are corollaries of some underlying single cause.

About the only justifiable conclusion regarding the phylogenetic relation between the sexual act and reduction is that they arose as adjacent phenomena. This seems probable, since in primitive forms, both plants and animals, they occur close together in point of time. It would seem, on a priori grounds, too, that if a sexual union occurred in forms that had been producing asexually, a reduction in the amount of chromatin would promptly occur if it had not occurred previous to the act, so as to restore customary conditions as speedily as possible. 
TIIE: PRINIITIV] ANTMAL TYPI:

lotanists sem agreed that the riguificance of the persistent gimetophyte in the higher plants is that it represents a return to a primitive type. The conclusion seems a proper one. We would similarly expect the gametozoic generation, then, to represent a primitive animal type. The spherical spermatophore, arising from a spermatogonium ats a spore might cleave, must find its counterpart in the phylogeny of the higher animals as the thallus-like gametophyte of the higher plants indicates a thalline ancestry for them.

Possibly the Volvocales approximate most closely to such an hypothetical ancestral form. The group is one that has bcen appropriated by many zoologists as showing marked animal affinities, and is admittedly a widely aberrant type by all botanists. Volvox reproduces asexually; certain cells of the central cavity, the so-called parthenogonidia, reproduce by fission, and the offspring divide and subdivide, the products cohering in spherical masses to form colonies like the parent. These are freed when the parent colony disintegrates. Volvox also reproduces sexually. Certain cells differentiate as eggs and come to lic in the interior of the colony. Other cells, similarly discharged to the interior, develop within them numerous sperm. 'The sperm break out of their containing cells and fertilize the eggs. The oospore remains inactive for some time as a resting spore but finally dovelops a colony like the parent. My preparations are not yet sufficiently clear to permit of working out all the chror matin changes, but I am quite positive that reduction occurs in Volvox, as it does in animals, during gametogenesis.

In the Dicyemidae, looked upon by many zoologists as the connecting link between the protozoa and the metazoa, the process of reproduction is suggestively similar, except that the asexually produced young bore out from the parent to an independent existence instead of awaiting the death of the parent. 'The center' of the dicyemid is oceupied by a cell, in which, besides the nucleus, there are one to several embryo cells from which the asexual individuals arise. These cells are evidently the homologues of 
those partherogonidia found in the Volvox colony. Max Hartmann, in describing the reproduction of the Dicyemidac, speaks of this central cell as the agametangium because in it develop the asexual, or as he calls them, the 'agamic' individuals. After several generations of these agamic individuals, there arise the rexual or the gametic individuals. They arise from the embryo cells (Tieimzellen of Hartmann) by a process of cleavage very similar to the development of the agamic individuals, except that in the female the reproductive cells are split off early. The female as well as the male sexual individual grows within the asexual parent. The eggs are developed from the embryo cells of the female. They are freed from the gametic individual into the socalled agametangium of the agamic individual by the death of the ganetic form. The egg matures by forming polar bodies and is fertilized by sperm which have discharged from the male gametic individual by its death and disintegration.

To harmonize Hartmann's description with the language I have used in giving the alternation of generations in the Arenicolidae I have only to change his terms sightly: (I have adopted the terminology proposed by Bcard, cited later). Call his agamic indivicuals the sporozoon and the Keimzellen spores; his gametic individual, the gametozoon; then the dicycmids make concrete our conception of how the altcrnation of generations of the higher forms arose from such simple ones as Volvox, even though the line of ascent may not actually have passed through the Dicyemidlate.

Imagine that in a Volvox-like form the sexual colony or gametozoon develops egges and sperm before it is discharged from the colony which reproducen asexually and the condition of the dicyemids i: practically achicred. Now imagine that a regular alternation of generations is established instead of the intercalation of an occasional sexual generation in the midst of the dominant asexual reproduction of the Dieyemidae and a condition is established that needs little if any modification to give the alternation of generations as we find it in the Arenicolidae, as follows:

The alult Arenieola, a sporozoon, corresponds to the sporophyte colony of Volvox or the agamie indiridual of the dicyemid. At 
some time in its life history cells are developed within its central cavity - the primitive germ cells or spore mother cells. These develop spores which we know as spermatogonia or oogonia. Such spores, in Volvox, develop new colonies which may be sexual and which are freed when the parent disintegrates. In the Dicyemidae, if a gametic individual develop from such spores (or Keimzellen) it is retained in the parent where it disintegrates to free its egg or sperm. In a word the gametozoon degenerates prematurely within the sporozoon. Now in Arenicola, I take it, the development of the spermatogonia into the spermatophores is the development of the gametozoa. Gametozoon degeneration begins before its development is complete and the sperm are produced by a short cut. Instead of developing an individual, within which some cells form the clusters of sperm, its cells form the sperm cluster immediately. In this genus, as I have already shown is the case in Hydra, the sperm seems to form within the spermatid, reminiscent perhaps of the primitive condition found in Volvox of forming the sperm within the cell.

For the sake of my theory, I should like to agree with Tannreuther in the spermatogenesis of Hydra. He claims that the spermatozoa develop in groups, each group enclosed within a single cell or cyst. But the clearness of my own preparations seems to negative completely such an interpretation. I can only reiterate what $I$ have already published on the spermatogenesis of this form. It is too bad, for Hydra would make even a better transition form than it does, between such a spermatogenesis as we have in Volvox and the typical animal spermatogenesis in which the spermatid transforms into the sperm in its entirety rather than developing the sperm within it.

Hartmann, in the paper on the Dicyemids, describes bricfly and figures a development of the fertilized egg that is very similar to the development of the asexual spores. The same parallelism is noted in many botanic papers, the onspore developing much as an asexual spore does in its early stages. To find, then, in Arenicola that the spermatogonia or asexual spores develop to produce the spermatophore or gametozoon in a manner homologous to the development of the fertilized egg is to strengthen the position taken that the spermatophore is the gametozoon. 
THE GAMETOZOON, A $2 \mathrm{X}$ TORM

Botanists, reasoning on the basis of the fact that the disappearing gametophyte in the higher forms possesses the haploid number of chromosomes, have been led to assume, not only that the gametophyte represents a reversion to the primitive type, but also that this primitive plant possessed the $x$ number of chromosomes. Reasoning in an analogous manner, we should be forced to assume, that, since the gametozoon possesses for most of its life history, the $2 x$ number of ehromosomes, so the primitive animal type did not have the reduced number. This distinction between plants and animals has long been recognized. "So far as groups of plants above the thallophytes are concerned, the period of chromosome reduction has been found to be always associated with sporogenesis and never with gametogenesis as in the case of animals." (Yamanouchi; Polysiphonia, p. 43.) The difference may help to trace the gradual separation of the plant and animal types in the course of evolution. Upon this distinction, for instance, Dobell rests his belief in the plant affinities of the Phytomonadina (The structure and life-history of Copromonas subtilis, p. 112). The discovery already mentioned that Volvox has reduction occurring during gametogenesis would justify, in a measure, the classification of the form as an animal rather than as a plant.

\section{THE COMMON P'ROTOTYPE}

Presumably plants and animals have come from a common ancestor. Now in all higher animals reduction occurs near the close of the gametozooic generation. It occurs, in all higher plants, near the close of the sporophyte generation. In the common ancestor it must have occurred at a point between these two extremes, possibly during or in close connection with the conjugation of the gametes. Such a possibility is rendered probable from the fact that, in thallophytes and protozoa, the reduction occurs at variable times in the life histories, usually as an adjunct of the union of the gametes, as if that variation were dominant which later becomes fixed in the two prevailing plant and animal types. 


\section{OLIGINAL POSITION OF REDUCTION}

If reduction originally occurred in the primitive common ancestor somewhere closely adjacent to the union of the gametes, the reduced number of chromosomes would exist for only a short period and might not occur at all. The major part of the life history of the forms would possess the somatic or diploid number. This is now the case for most animals and for many of the algae as already shown. In plants, then, the place of reduction in the life history has been shifted; the phenomenon has been postponed. In animals it occurs much nearer its original position.

\section{Reduction shifted}

Since in practically all animals and in many algae, the phenomenon of reduction occurs before or during conjugation of the gametes, the preponderance of evidence appears in favor of such a position in the primitive common ancestors of plants and animals. It is all the animals and many algae against the higher plants in favor of such an hypothesis. Text fig. 7, then, might nearly represent primitive conditions. Evidently following the gamete-bearing generation with it definite number of chromosomes would come a spore-bearing generation with the same number of chromosomes. This is true now in the Conjugales, Coleochaete, etc., and I belicve in Volvocales and the animals. True, in Conjugales, Volvocales, etc., there are scveral spore-bearing generations following each other in succession. But if, for any reason, the alternation of generations be established by the omission of all but one of these spore-bearing generations, there would be left the gametophyte and sporophyte generations as I conceive them to exist in Arenicola, only that the reduction has shifted from a position like that of fig. 7 of the text to a place before the conjugation of the gametes. For plants the shift in position has been in the opposite direction-a shift that is seen progressing in text fig. 6 and completed in fig. 5 .

In Chamberlain's theory of the alternation of generations in animals, he maintains that the shift in the animal group has 
been in the same direction as in the higher plants. As pointed out by Coulter and Wiss Pace, the end result attained in plants by the gradual reduction of the gametophyte generation to the point of complete extermination, in such forms as Pandanus, is entirely similar to the condition found in animals. Because the end results are similar is not prima facia evidence that the means of achievement in the course of evolution have been the same; it is rery evident that in the higher plants such a condition as is found in Cypripedium, ete., is the result of a reduction on a gametophyte generation with the $x$ number of chromosomes, for all steps in the process are eridently traceable. But nowhere in the animal kingdom, not even among the protozoa, is there any evidence of a corresponding gametozoic generation with a reduced number of chromosomes.

\section{REDLCTION ANI TETRAD-FORMITION}

It is true that there is a striking similarity between the formation of the tetraspores in most plants and the development of the spermatids from the spermatocyte. It is rendered doubly suggestive by the fact that reduction occurs during both processes. Yet, even in the plants themsclves, wo are not warranted in concluding that all cells in which reduction occurs are homologous. Reduction occurs without tetraspore formation in a sufficient number of cases, as in Lemanea, Chantransia, etc., to show that there is no fundamental phylogenetic association involved. The customary appearance of a fourfold division at time of reduction may be based on some fundamental property of carbon compounds, possibly on the tetravalent condition of carbon itself; in which case it would not be strange to find tetrad formation common in plants and animals without assuming that, when occurring, a morphological homology is indicated.

\section{BEARD'S HYPOTHESIS}

In the preceding pages I have noted one hypothesis of the alternation of generations in animals - that proposed by Chamberlain, and I have given my reasons for discarding it. Another 
hypothesis of the alternation of generations in animals has been proposed and vigorously advocated by Beard. He recognizes an antithetic alternation of generations in animals. He, too, identifies "the primary germ cells as the equivalents of the sporemother-cells of plants." He regards the larva or phorozoon as the asexual generation, the homologue of the sporophyte. He derives the gametozoon, the adult animal, from it by apospory. $\mathrm{He}$ is forced to conclude, then, "that the final reduction of chromosomes has been deferred to a later portion of the life cycle in metazoa as compared with plants."

The same objections apply to Beard's hypothesis as to Chamberlain's, namely, that there is no evidence in fact of the successive steps in the postponement of reduction in animals similar to that so constantly apparent in plants. So far as we know, the process always occurs closely adjacent to the union of the gametes, continuing, in the higher animals, in much the same position in the life cycle that it occupies in the lower animals and plants. Whereas, in plants, it is evidently shifted from this primitive position and the successive steps of the shift are traced with some degree of certainty in living forms.

Furthermore, it seems to me, an impossible task to articulate his theory with what we know of the reduction phenomena and the development of the protozoa and mesozoa. He says:

The sexual generation of plants is at best a miserable failure from the morphological point of view. . . . The higher one ascends the smaller it becomes until in the higher plants it has almost reached the vanishing point, without, however, being able to disappear entirely.

In the animal it is the larva, the phorozoon, or asexual generation which makes the bravest show in the lower metazoa; . . . In the higher forms it becomes reduced.

But how will a relation be established between the larva of the metazoa and the asexual generation of the protozoa? The one should pass over into the other. It seems unwise to adopt a theory which demands a hiatus at this point, when it is easy to blaze a possible, uninterrupted trail along which evolution may have proceeded by way of such forms as the Volvocales and the Dicyemidae, if we adopt the hypothesis I have proposed. 


\section{BIBLIOGRAPHY}

Allen, Chas. F. 1905 Die Keimung der Zygote bei Coleochaete. Ber. deutsch. bot. Gesells., Bd. 33: p. 286.

DeBARrx, A. 1878 Ueber apogame Farne und die Erscheinung der Apogamie im Allgemeinen. Bot. Zeit., Bd. 36: pp. 449-487.

BEARD, J. 1902 Heredity and the epicycle of the germ-cells. Biol. Centralbl., vol. 22 : pp. 321-328, 353-360, 398-408.

Beard, J. ANd Murray, J. A. 1895 On the phenomena of reproduction in animals and plants. Ann. of Bot., vol. 9: pp. 441-468.

Bütschli, O. 1876 Studien über der ersten Fntwicklungsvorgänge der Eizelle, der Zelltheilung und die Conjugation der Infusorien. Abh.d.Senckenb. naturf. Gesell. Fr. a. M., Bd. 10: pp. 213-452.

Calkins, Gary N. 1895 The spermatogenesis of Lumbricus. Jour. Morph., vol. 11, no. 2: pp. 271-302.

Chambertain, C. J. 1905 Alternation of generations in animals from a botanic standpoint. Bot. Gaz., vol 39: pp. 137-144.

1910 Nuclear phenomena of sexual reproduction in Gymnosperms. Am. Nat., vol. 44: pp. 595-603.

Child, Chas. M. 1900 The early development of Arenicola and Sternapsis. Arch. f. Entw. der Org., Bd. 9: pp. 587-717.

Coulter, John M. 1908 Megaspores and embryo sacs. Bot. Gaz., vol. 45: pp. $361-366$.

Coulter, Barnes, Cowles 1910 Text book of botany. Chicago.

Dangeard, P. A. 1898 Sur les Chlamydomonadinées. C. R. Ac. Sci., Paris, Tome 127: p. 736 .

Davis, B. M. 1905 On the plant cell, vi and vir. Am. Nat.. vol. 39: nn. 449500 and $555-600$.

1909 Origin of the Archegoniates. Am. Nat., vol. 43: pp. 107-111.

Doseld, C. C. 1907 Physiological degeneration in Opalina. Q. J. Micr. Sci., vol. 51 : pp. 633-8:46.

1908 The structure and life-history of Copromonas subtilis. Q. J. Micr. Sci., vol. 52: pp. 75-120.

1909 Chromidia and the binuclearity hypothesis. Q. J. Micr. Sci., vol. 53: pp. 279-326.

Downing, E. R. 1905 The spermatogenesis of Hydra. Zool. Jahrb., Abt. f. Anat. u. Ont., Bd. 21: pp. 379-426.

1909 The connections of the gonadial blood vessels and the form of the nephridia in the Arenicolidae. Biol. Bul., vol. 16: pp. 246-258. 
Farmer, J. B. ANd Digby, L. 1907 Studies in apospory and apogany in forns. Ann, of Bot., rol. 21: pp. 161-199.

Farver, P. 1899 Arenicola ecaudata. Nem. Soc. Sei. Nit. Cherbourg., Tome 31: pp. 101-186.

Gamble, F. W. ANI Ashworth, J. H. 1900 The anatomy and classilication of the Arenicolidae. Q. J. Micr. Sci., vol. 43: pp. 419-569.

Hartmann, Max 1906 Untersuchungen über den Generationswechsel der Dicyemiden. Brussels. Also in Mem. of Ruyal Belorian Ae.ul., X.s., vil. 1.

Hertwig, R. 1896 Ueber Ijerntheilung, Richlungshörperbildung liid Befruchtung von Actinosphaerium eich., Abh. d. k. bay. Mkat. d. Wis... München, II Kl. 19: pp. 1-104.

Hoyт, W. D. 1909 Alternation of generations and sexuality in Dictyot:a dichiotoma. Bot. Gaz., vol. 49: pp. $5 \tilde{u}-57$.

Farsten, G. 1909 Die Entwichlung der Zygoten vou Spirogyra jugalis Kitzr., Flora, vol. 99: p. 1.

LILLIE, RALPH S. 1905 The structure and development of the nephridiz of Arenicoli cristata Stimpson. Mitth. a. 1. zool. Stat. z. Teapel, Ba1.17: pp. 341-405.

LoBianco, s. 1899 Mitth. a. d. zool. Stit. z. Neapel, Bd. 13: p. $4 \$ 4$.

Meyer, Eo. 1901 Studien über der Körperbau der Anneliden, III. Mitth. a. d. zool. Stat. z. Nearel, Bd. 14: pp. 2tī-j85.

Metcalf, Marnard M. 1908 Opalina. Its auatomy and reproduction, with in description of infection experiments and il chronological review of the literature. Arch. f. Protist. Bd. 13: pp. 195-374.

Nereshermer, E. 1907 Die Fortplanzung der Opalinen. Arch. Protistenk, Suppl. 1: pp. i-43.

Pace, Lubu 1907 Fertilization in Cypripedium. Bot. Gaz.. vol. 44: pp. 353374.

Prowazek, S. von 1901 Kerntheilung und Vermehrung der Polytoma. Üst. bot. Zeitschr., Bd. 51: p. 51, etc.

1901 Flagellatenstudien. Arch. Protistenk. 2: pp. 195-212.

Schenk, H. 1908 Ueber die Phylogenie der Archegoniaten und der Characeen. Engler's Bot. Jahrb. Bd. 42: pp. 137.

Schaudinn, F. 1896 Ueber die Copulation von Actinophrys sol. Sitzber. Akad. Wiss., Berlin. Bd. 1: pp. 83-89.

Strasburger, Ed. 1904 Die Apogamie der Eualehemillen und allgemeine Gesichtspunkte die sich aus ihr ergeben. Jahrb. wiss. Bot., Bd. 41: pp. 88-164.

Sindlecki, M. 1899 Etude cytologique et cycle evolutif de Adelea ovata Schneider. Ann. Inst. Pasteur, Tome 13: pp. 169-192. 
Tannaeuther, G. W. 1909 Observations on the germ-cells of Hydra. Biol. Bull., vol. 16: pp. 205-209.

Wriliams, J. Lloyd 1904 Studies in the Dictyotacege. Ann. of Bot., vol. 18: pp. 140-160 and 183-204.

Wolrk, J. J. 1904 Cytological studies in Nemalion. Ann. of Bot., vol. 18: pp. (i0)-(i3).

Yamanovehi, SHIGío 1906 The life history of Polysiphonia. Bot. Gaz, vol. 42: pp. $401-449$.

1908 Apoganny in Neiphrodium. Bot. Ciaz., vol. 45: pp. 289-318. 
THE SPERMATOPHORF IN ARENICOLA

FLIIOT ROWLAND DOWNING

PLATE 1

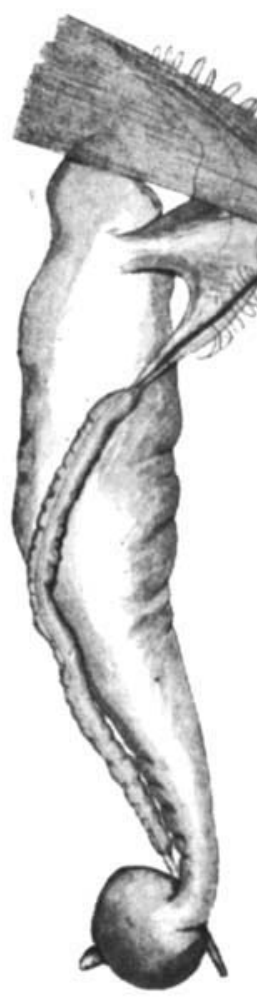

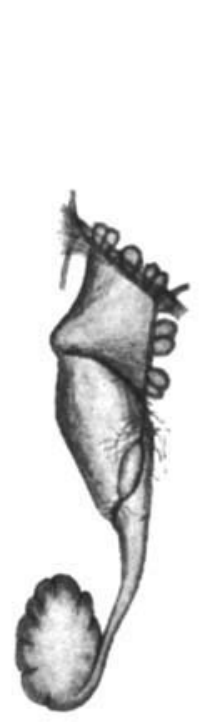

5

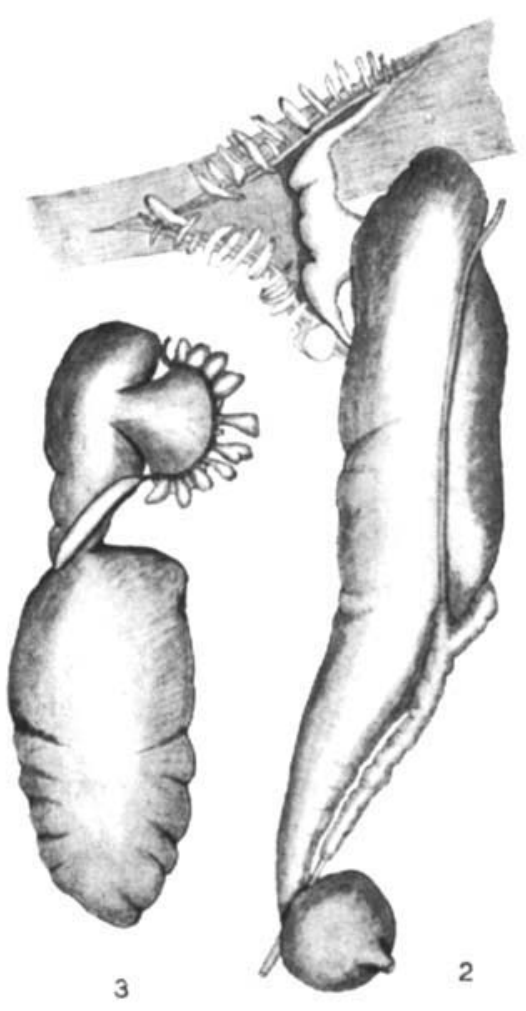

3

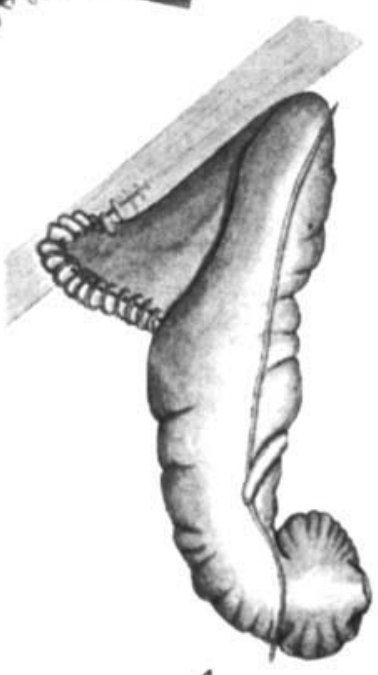

4

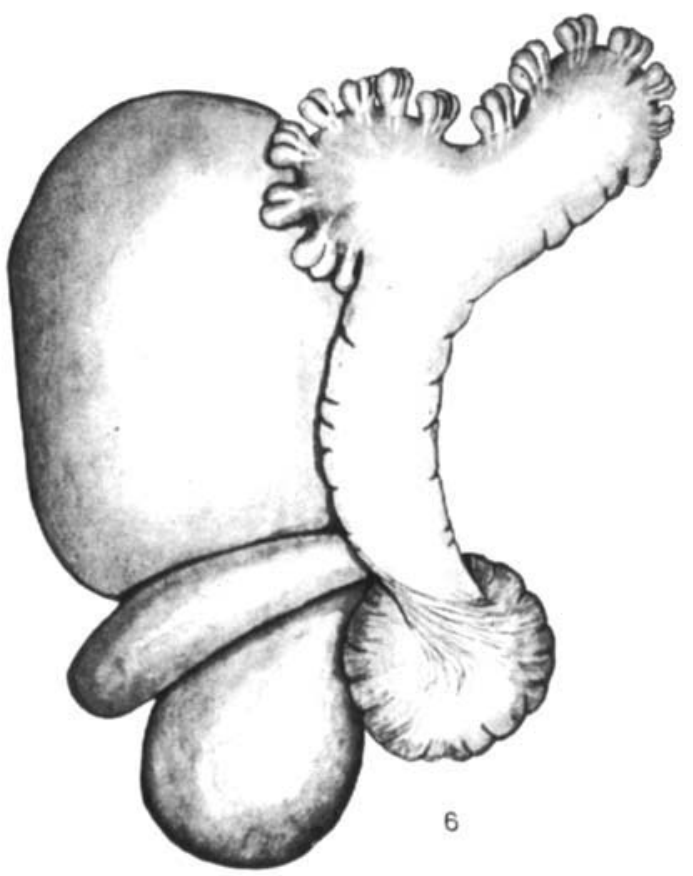

JOERNAL OF MORPHOLOGY, YOL, 22 , NO. 4 


\section{PLATE 2}

EXPLANATION OF FIGURES

7 Section through the testis of A. cristata in October. It corresponds to the dotted portion of text fig. 1 . The cells are some $7.5 \mu$ in diameter.

8 Section through a testis of A. cristata in February. It corresponds to the dotted portion of text fig. 2. Fibrous degeneration and phagocy tosis are apparent.

9 Section through the testis of $A$. cristata; numerous spermatophores are forming. 
THE SPERMATOPHORE IN ARENICOLA

PLA'TE 2

FLLIOT HOWLAND DOWNING
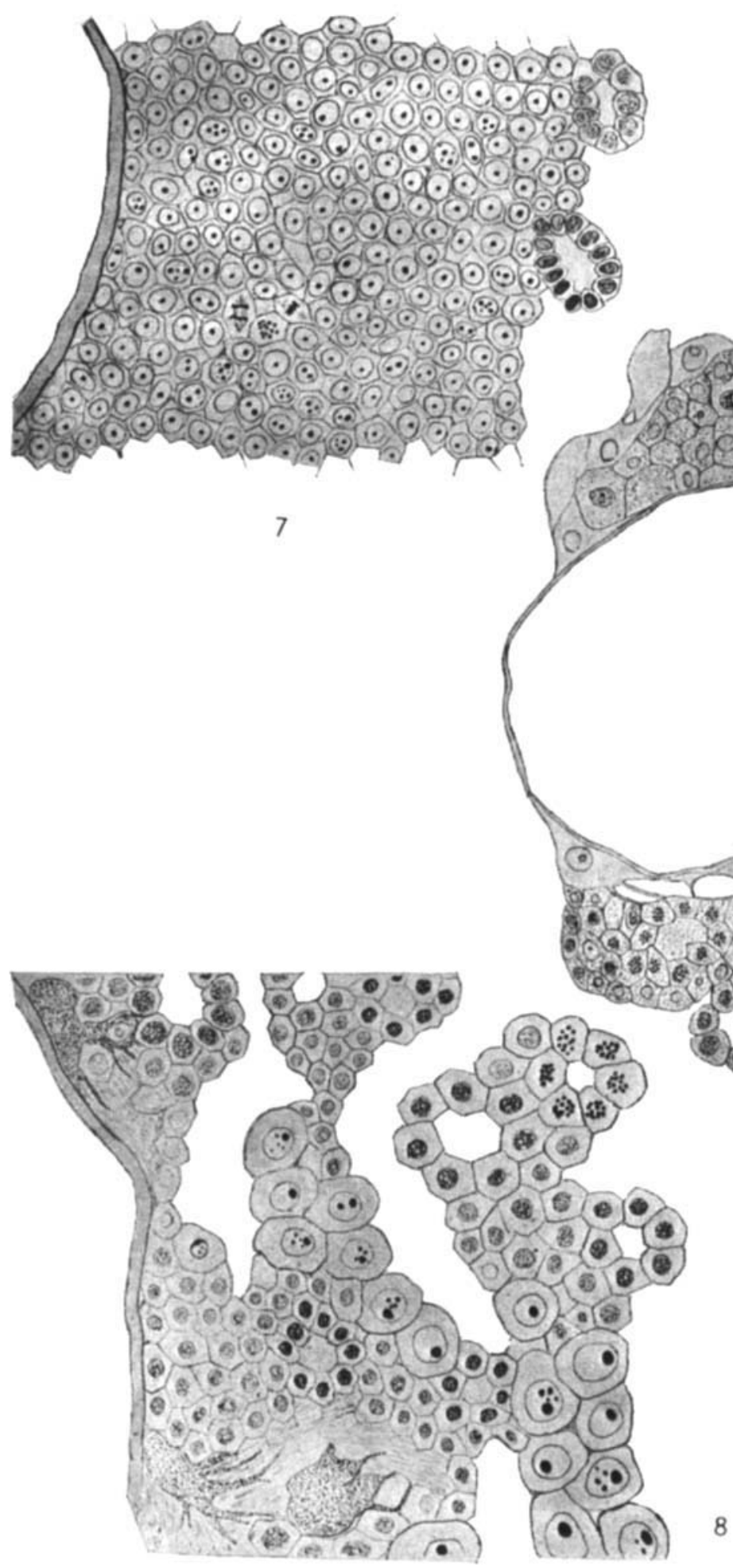


\section{PI.ATE 3}

\section{EXPTANATION OF FIGURES}

10 A spermatophore from the body fluid of A. cristata. These cells are the sixth generation of spernıatogonia from the primary spermatogonia. Each divides to form the last spermatogonial generation. The cells have an average diameter of $3.5 \mu$. All are in the equatorial plate stage. $\times 340$.

11 A spermatophore from the body fluid of A. cristata. The cclls are the spermatids just after the division of the spermatocytes of the second division. They are in the early anaphase. $\times 340$.

12 A mature spermatophore of A. cristata. Smear preparation fixed in vom Rath's fluid and stained in saureviolett and iron hacmatoxylin. $\times 625$.

13 Body fluid of A. cristata under low power, showing spermatophores in various stages ( $a, b, c)$, and coelomic cells (d), leucocytes and chloragogue cells. $\times 100$.

14 A phagocyte from testis of A. cristata in April. $\times 930$. Note the ingested cell.

15 An early stage in the formation of a spermatophore, from the body fluid of A. cristata. Diameter of the spermatophore $32 \mu$; average diameter of the cells 7.5 . 


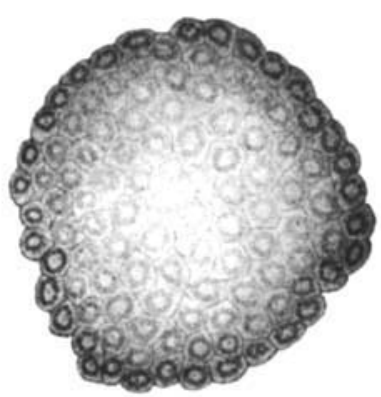

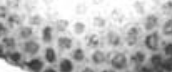

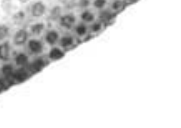

11

10

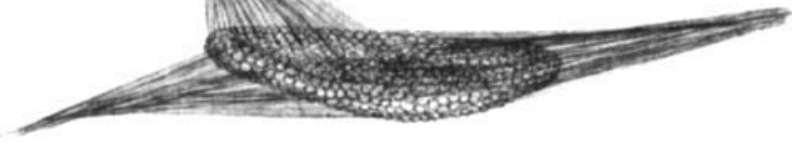

12

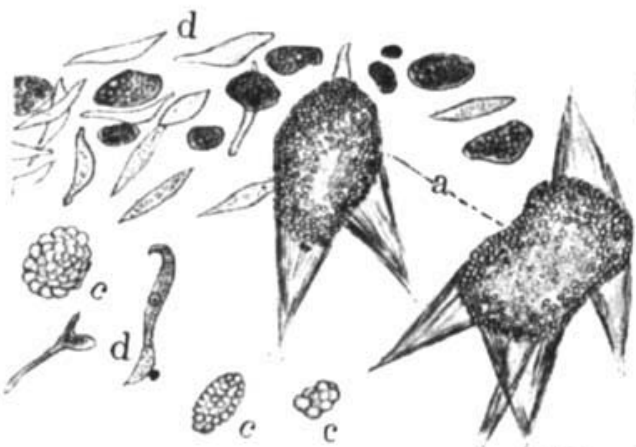

8 कि
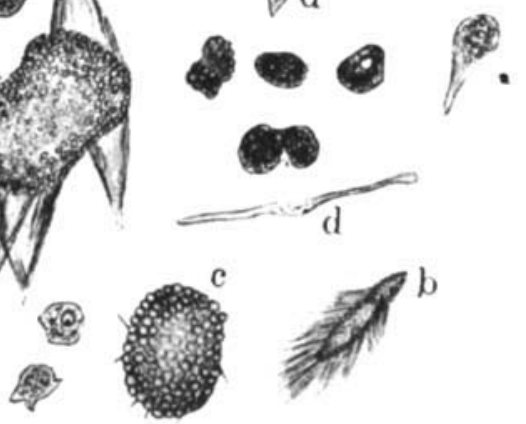

ब्रिजि

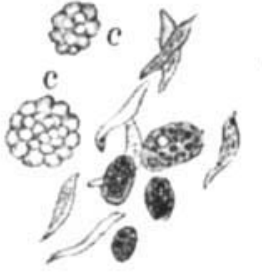

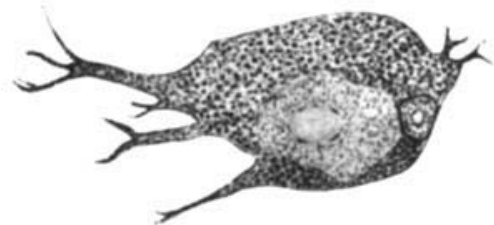

14

(2)

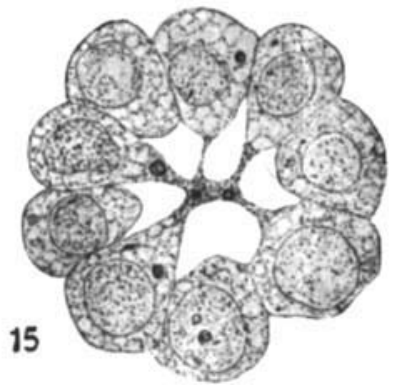

JOURNAL OF MORPHOHOGY, voL. 22 , No. 4 


\section{PLATE 4}

\section{EXPLANATION OF FIGURES}

16 Section of a more typical spermatophore. $\times 1250$.

17 A giant spermatogonium. $\times 1800$.

18 A giant spermatogonium dividing, the two-cell stage.

19 A giant spermatogonium dividing, the four-cell stage, polar view.

20 A giant spermatogonium dividing, the eight-cell stage, side view.

21 A giant spermatogonium dividing, the eight-cell stage, polar view.

22 A giant spermatogonium dividing, the sixteen-cell stage, polar view.

23 A later stage in segmentation of a spermatogonium, a spermatophore from the body fluid of $A$. cristata.

24 The 'invagination' of the forming spermatophore in A. cristata.

25 Section through the saucer-shaped spermatophore of A. cristata. The cells are spermatids, $1 \frac{1}{4} \times 4 \mu$. 
T" F: SPIERMATOPHORE IN ARENICOLA

IELIOT ROWLAND DOWNING

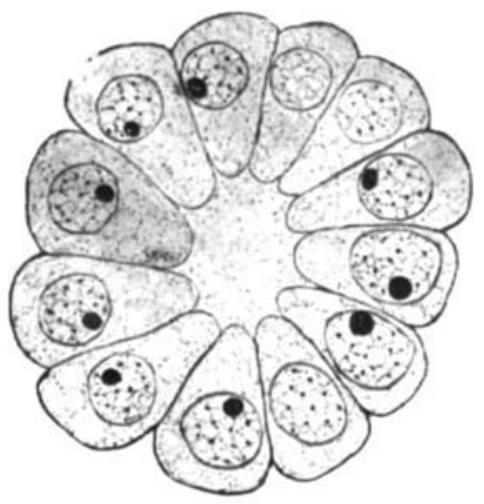

16

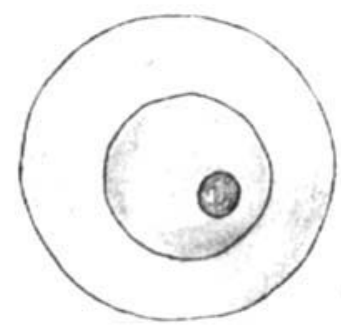

17
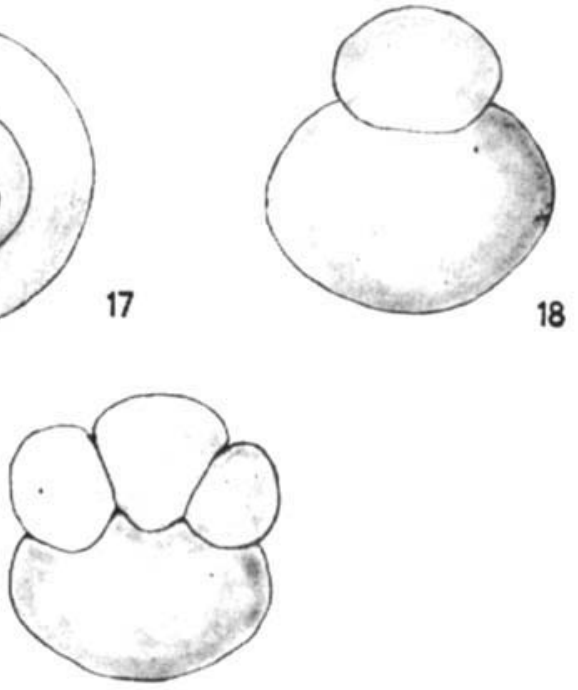

19

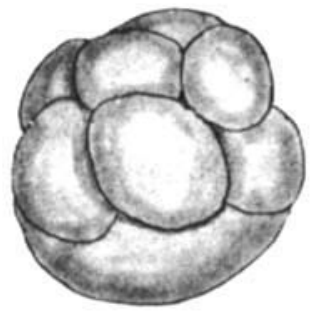

20
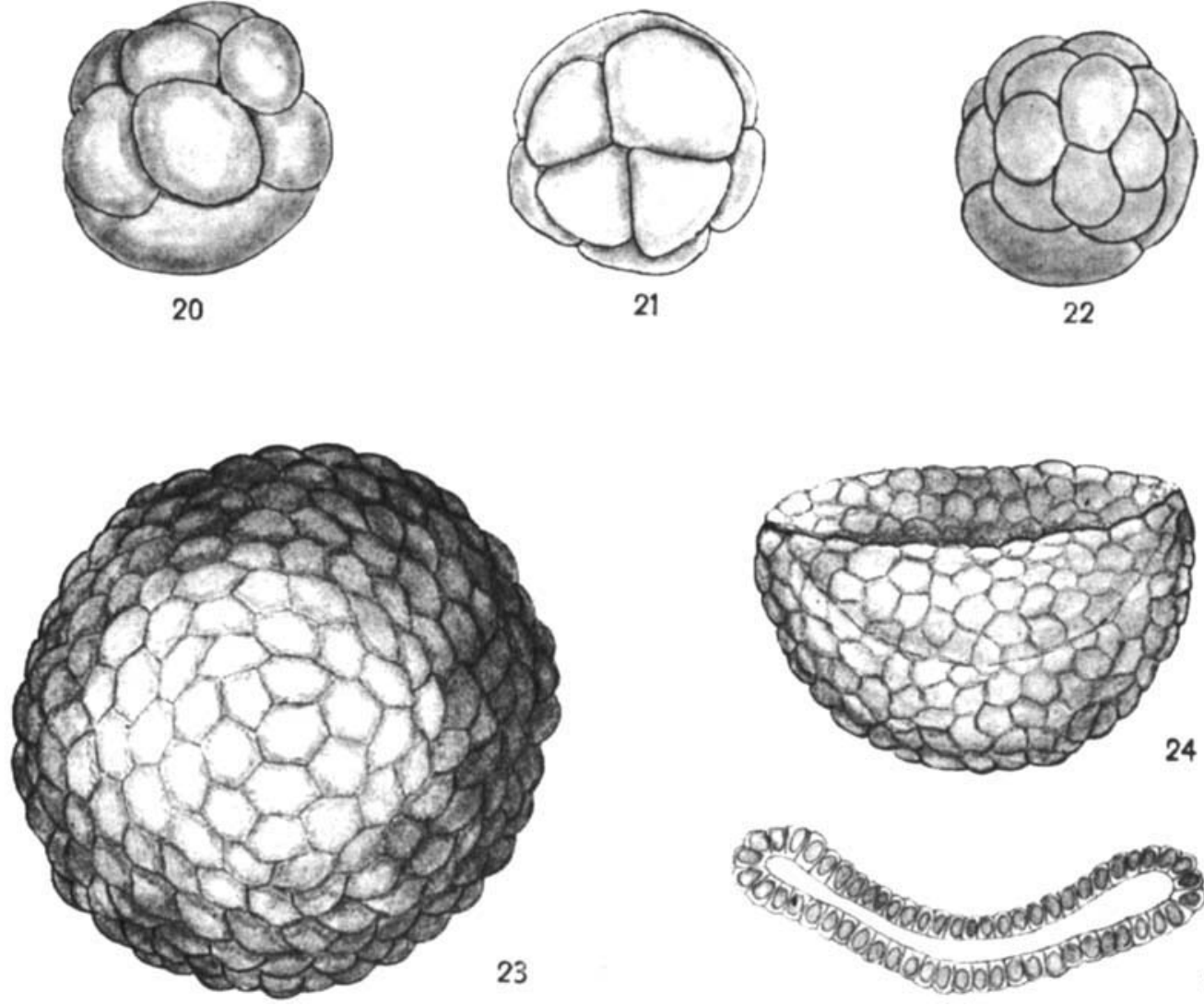

JOERA1 OF Vomblotogr, vot, 22, w 